DOI: $10.17805 /$ trudy.2016.6.13

\title{
XIII МЕЖДУНАРОДНАЯ НАУЧНАЯ КОНФЕРЕНЦИЯ «ВЫСШЕЕ ОБРАЗОВАНИЕ ДЛЯ ХХІ ВЕКА»
}

\author{
Ч. К. Ламажаа \\ (Московский гуманитарный университет)
}

Аннотация: В статье представлен обзор работы ХІІІ Международной научной конференции «Высшее образование для ХХІ века», которая прошла в Московском гуманитарном университете 8-10 декабря 2016 г.

Ключевые слова: конференция; обзор; Московский гуманитарный университет; высшее образование; «Высшее образование для ХХІ века»

\section{$13^{\text {TH }}$ INTERNATIONAL RESEARCH CONFERENCE “HIGHER EDUCATION FOR 21 ${ }^{\text {sT }}$ CENTURY"}

\author{
Ch. K. Lamazhaa \\ (Moscow University for the Humanities)
}

Abstract: This is a summary of the 13th International research conference "Higher education for 21st century" which was held at Moscow University for the Humanities on December 8-10, 2016.

Keywords: conference; overview; Moscow University for the Humanities; higher education; "Higher education for the 21st century"

В Московском гуманитарном университете 8-10 декабря 2016 г. прошла XIII Международная научная конференция «Высшее образование для XXI века».

На пленарном заседании, которое открылось 8 декабря в конференцзале 3-го учебного корпуса университета, ректор МосГУ, доктор философских наук, профессор И. М. Ильинский напомнил постоянным участникам и сообщил новым слушателям цели и задачи этого научного форума, который в этом году проводится уже тринадцатый раз. Он сделал краткий экскурс в историю широкого рассмотрения проблем образования во взаимосвязи с проблемами развития человечества и окружающей среды, в кото- 
рую входит не только природа, но и социум. Для современности огромное значение имеет Всемирная конференция «Окружающая среда и развитие», которая проходила в 1992 г. в Рио-де-Жанейро. Главным средством для перехода общества на новый путь развития было названо образование. По-новому образованный человек в XXI веке не позволил бы повторить ошибки человечества XX века, который еще называют «кровавым». Во «Всемирной декларации о высшем образовании для XXI века: подходы и практические меры», которую провозгласила ЮНЕСКО в 1998 г. по итогам Всемирной конференции по высшему образованию в г. Париже, говорилось, что очевиден «беспрецедентный спрос на высшее образование и его широкой диверсификации наряду со все большим осознанием его решающего значения для социально-культурного и экономического развития и создания такого будущего, в котором более молодые поколения должны будут овладевать новыми навыками, знаниями и идеями».

К сожалению, проблематика, которая поднималась на этом форумесобытии (на котором принимали участие большое число глав мировых государств), прошла почти незамеченной для России, для российской общественности, переживавшими сложные 1990-е годы.

Однако, и для мировой общественности выдвинутые новые идеи и принципы конференции оказались неподъемными. Наступил XXI век и все ожидания на то, что сразу наступит век благоденствия - не оправдались. Век начался с трагических событий, в том числе атаки на «башниблизнецы» 11 сентября 2001 года. Международный терроризм, войны, цветные революции, кризис на Украине, Сирия...

В образовании же сейчас, подчеркнул И. М. Ильинский, происходит американизация и в этой связи Болонский процесс следует рассматривать как политический прежде всего.

В видеобращении первого заместителя председателя комитета по науке и образованию Государственной Думы ФС РФ, доктора философских наук, профессора О. Н. Смолина, которое он направил участникам конференции, также был представлен критический взгляд на проблемы современного образования, прежде всего российского. Парламентарий перечислил несколько ключевых проблем системы высшего образования, в том числе проблемы финансирования, дебюрократизации, проблемы современных технологий и проблемы воспитания. Он подчеркнул, что категорически не согласен с распространяющимся подходом о том, что стало слишком много высших учебных заведений в стране, слишком много студентов. «Образования слишком много не бывает», - убежден известный эксперт в этой области. Есть статистически подтвержденные результаты исследований о том, что люди с высшим образованием живут дольше, работают лучше, более ответственны и пр. 
Помимо этого, О. Н. Смолин не согласен с представлением о системе образования как сферой обслуживания, а также с тем, что педагогические работники - люди, предоставляющие услуги. Это совсем две разные области. Образование должно быть более свободным, более социальным, считает он.

Широкий социальный фон, на котором становятся понятными особенности реформирования системой образования, обрисовал слушателям директор Центра русских исследований Института фундаментальных и прикладных исследований Московского гуманитарного университета, кандидат исторических наук А. И. Фурсов. Двадцать пять - двадцать семь лет мы живем в состоянии кризиса, сказал он, и этот кризис наблюдается как во всем мире, так в нашей стране, и в системе образования. В мировых трендах мы наблюдаем, по мнению докладчика, демонтаж институтов модерна. Если ранее, в эпоху модерна, были нужны специалисты и администраторы, то сейчас, в эпоху постмодерна, когда главным фактором производства становится капитал, стали нужны уже люди с иной подготовкой. Он упомянул о футуро-архаизации как форме демонтажа, о реформировании, целью которой является разрушение. В нашей стране, где основным капиталом всего национального достояния владеет лишь малая часть населения, точнее - чуть более 105 тысяч человек, то есть олигархи, им образование население не нужно. Именно поэтому система образования целенаправленно разрушается...

Проблемы национальной безопасности поднял в своем выступлении главный научный сотрудник Института проблем информатики Федерального исследовательского центра «Информатика и управление» РАН, доктор технических наук, профессор К. К. Колин. Он назвал знаковые события в мировой геополитике и увязал их с принятыми российскими документами последних лет, в том числе Стратегию развития России до 2035 г.

Критический разбор концепции «Образование 2035», которое разработало Агентство стратегических инициатив в 2013 г., выполнила доцент кафедры истории и политики стран Европы и Америки МГИМО МИД РФ, кандидат исторических наук О. Н. Четверикова. Она выступила с развернутым докладом на эту тему перед участниками пленарного заседания. Как сказала докладчик, если раньше новые технологии меняли нашу реальность, то теперь они меняют самого человека. Принять такие изменения нормальный человек уже не может, поскольку они не вписываются в традиционные христианские и даже просто в гуманистические ценности. В этом же русле происходят изменения в образовании, науке, культуре, когда перед нами разворачивается фактически расчеловечивание.

Раньше мир делился на «золотой миллиард», напомнила О. Н. Четверикова, и развивающиеся страны. Сейчас к этой градации добавляет- 
ся технологический суперкластер (в зоне «золотого миллиарда») и зона управляемой нестабильности в общей зоне нищеты. Основным продуктом, за которым теперь охотятся развитые страны, стали таланты. Разрушаются барьеры между военными и гражданскими, экономика работает одновременно на общество и на военную сферу.

Принципиальные ошибки в процессе модернизации образования сформулировал профессор кафедры регионоведения Московского гуманитарного университета, доктор географических наук А. Ю. Скопин. О новых стратегиях образования в связи с технологическими новациями в области «улучшения человека» рассказала руководитель Центра научноинформационных исследований по науке, образованию и технологиям ИНИОН РАН, доктор философских наук Е. Г. Гребенщикова. Она сообщила о наборе в Международную школу молодых ученых, которая пройдет в Московском гуманитарном университете в конце июня 2017 г.

По окончании пленарного заседания участники смогли продуктивно обменяться мнениями в ходе личных бесед. Продолжение обсуждений состоялось в рамках работы секций и круглых столов 8 и 9 декабря, а также конференции аспирантов 10 декабря.

Круглые столы заседали по темам: «Негосударственные вузы в условиях современной России» (руководители - ректор МосГУ, д. ф. н., профессор И. М. Ильинский, ректор Национального института бизнеса, д.ф.н., профессор С. И. Плаксий); «Политология перед вызовами XXI века» (руководители - профессор кафедры философии, культурологии и политологии МосГУ, д. п. н., профессор В. И. Буренко, заведующий кафедрой политологии и государственного управления Российской академии народного хозяйства и государственной службы при Президенте РФ, д. п. н., профессор О. Ф. Шабров); «Интеграционные модели на Востоке и Западе: сравнительный анализ» (руководитель - заведующий кафедрой международных отношений и дипломатии МосГУ, д. и. н. Н. Н. Платошкин); «Профессиональная подготовка в сфере массмедиа» (руководители -декан факультета рекламы МосГУ, д. и. н., профессор А. Д. Бородай, заведующий кафедрой журналистики МосГУ, д. культ., доцент Ю. А. Головин, ведущий научный сотрудник проблемной научно-исследовательской лаборатории по изучению актуальных проблем журналистики кафедры периодической печати МГУ им. М. В. Ломоносова, д. филол. н., профессор М. В. Шкондин); «Особенности подготовки студентов художественнотворческих направлений в гуманитарном вузе» (руководитель - заведующий кафедрой культуры и искусств, заместитель декана факультета культуры и искусств МосГУ А. А. Чванов); «Оптимизация преподавания филологических дисциплин в вузе» (руководитель - заведующая кафедрой иностранных языков и лингвистики МосГУ, к. п. н., доцент С. Ф. 
Щербак); «Высшее образование и развитие человека» (руководители главный научный сотрудник Института философии РАН, директор Центра биоэтики Института фундаментальных и прикладных исследований МосГУ, д. ф. н., член-корреспондент РАН Б. Г. Юдин, директор Института фундаментальных и прикладных исследований МосГУ, д. ф. н., професcop В. А. Луков, заведующий сектором биоэтики Института философии РАН, д. ф. н., профессор П. Д. Тищенко); «Формирование экологической культуры обучающихся» (руководитель -проректор по инновационному развитию Московского гуманитарного университета, к. п. н., доцент Н. И. Ильинская). Секции работали по следующим направлениям: «Философия образования» (руководители секции - Воскобойников А. Э., профессор кафедры философии, культурологии и политологии МосГУ, д. ф. н., профессор, Турбовской Я. С., заведующий лабораторией философии образования Института теории и истории педагогики РАО, председатель Совета директоров школ стран СНГ, член Общественной палаты по образованию г. Москвы, д. п. н., профессор), «Социология образования» (руководители секции - Ковалева А. И., проректор Московского гуманитарного университета, заведующая кафедрой социологии Московского гуманитарного университета, д. с. н., профессор; Зубок Ю. А., руководитель Центра социологии молодежи Института социально-политических исследований РАН, д. с. н., профессор), «Экономика образования» (руководители секции - Башина О. Э., заведующая кафедрой статистики, маркетинга и бухгалтерского учета МосГУ, д. э. н., профессор, Крылова Е. Б., заведующий кафедрой экономических и финансовых дисциплин МосГУ, д. э. н., профессор, Царегородцев Ю. Н., заведующий кафедрой менеджмента МосГУ, директор ИППК ГУ-ВШЭ «Интеллектуальный капитал предприятий», д.э.н., профессор), «Психологические проблемы образования» (руководитель секции - Журавлев А.Л., директор Института психологии РАН, заведующий кафедрой социальной и этнической психологии Московского гуманитарного университета, академик РАН), «Проблемы культурологического образования» (руководитель секции - Костина А. В., декан факультета философии, культуры и искусства, заведующая кафедрой философии, культурологии и политологии МосГУ, д. ф. н., д. культ., профессор), «Проблемы юридического образования» (Сошникова Т. А., заведующая кафедрой гражданского процесса и социальных отраслей права МосГУ, д.ю. н., профессор); «Проблемы исторического образования» (руководитель - Алексеев С. В., заведующий кафедрой истории МосГУ, д. и. н., профессор), «Педагогика и образование» (руководитель - Ситаров В. А., заведующий кафедрой педагогики и психологии высшей школы МосГУ, д.п. н., профессор). Свое очередное заседание провел и симпозиум «Тезаурусный анализ мировой культуры» (руководители - Захаров Н. В., дирек- 
тор Центра теории и истории культуры ИФПИ МосГУ, доктор философии, Трыков В. П., заместитель заведующего кафедрой всемирной литературы по научной работе Московского педагогического государственного университета, д. филол. н., профессор, Лисович И. И., профессор кафедры философии, культурологии и политологии Московского гуманитарного университета, д. культ.).

Материалы заседаний были изданы сборниками до начала конференции, они будут загружены в базу данных РИНЦ. Тексты отдельных докладов будут опубликованы в журналах «Знание. Понимание. Умение», «Ученый совет», «Научные труды Московского гуманитарного университета».

Всего для участия в конференции зарегистрировались около 500 человек. В их числе 10 академиков, члена-корреспондентов Российской академии наук, Российской академии образования, других государственных академий и общественных международных академий, 8 заслуженных деятелей науки и деятелей культуры Российской Федерации, 16 ректоров и проректоров вузов, директоров НИИ и научно-исследовательских центров, 12 деканов и заместителей деканов факультетов российских вузов, 55 заведующих кафедрами вузов и руководителей подразделений научноисследова-тельских институтов, 118 докторов наук, 177 кандидатов наук.

Традиционно обширна география конференции. В этом году участники представляют 25 российских городов, таких как: Арзамас, Балашиха, Белгород, Вологда, Воронеж, Екатеринбург, Иваново, Ижевск, Казань, Краснодар, Магнитогорск, Орел, Ростов-на-Дону, Санкт-Петербург, Саранск, Симферополь, Сочи, Таганрог, Тверь, Томск, Тула, Уфа, Харьков, Челябинск. В конференции участвуют представители 4 зарубежных стран: Беларуси, Казахстана, Польши, Колумбии. В целом, с учетом 12 прошедших конференций, география участников представлена примерно 70 российскими городами и 35 странами мира.

Дата поступления: 15.12.2016 г.

Ламажаа Чимиза Кудер-ооловна - доктор философских наук, заместитель директора Института фундаментальных и прикладных исследований Московского гуманитарного университета. Адрес: 111395, Россия, г. Москва, ул. Юности, д. 5, корп. 6.Тел.: +7 (499) 374-59-30. Эл. адрес: chlamazhaa@mosgu.ru

Lamazhaa Chimiza Kuder-oolovna, Doctor of Philosophy, Deputy Director, Institute of Fundamental and Applied Studies, Moscow University for the Humanities; Full Member, International Academy of Science (Innsbruck, Austria). Postal address: 5 Yunosti St., 111395, Moscow, Russian Federation. Tel.: +7 (499) 374-75-95. E-mail: chlamazhaa@mosgu.ru 


\section{Для цитирования:}

Ламажаа Ч. К. ХІІІ Международная научная конференция «Высшее образование для XXI века» [Электронный ресурс] // Научные труды Московского гуманитарного университета. 2016, № 6. URL: http://journals.mosgu.ru/trudy/article/view/384 (дата обращения: дд.мМ.гг.). 